\title{
Effects of microalgae and food limitation on the recolonization of benthic macrofauna into in situ saltmarsh-pond mesocosms
}

\author{
Karen I. Stocks*, J. Frederick Grassle \\ Institute of Marine and Coastal Sciences, 71 Dudley Road, Rutgers University, New Brunswick, New Jersey 08901, USA
}

\begin{abstract}
This study examined the effects of food limitation, in the form of reduced microalgae, on the recolonization of benthic macrofauna into intertidal saltmarsh-pond mesocosms. Eight tanks (1.4 m diameter) were dug into the intertidal Spartina alterniflora zone of a New Jersey saltmarsh, filled with a layer of defaunated mud, and allowed to recolonize naturally. Shading over 4 of the ponds reduced the light reaching the pond bottoms by $92 \%$ and the standing stocks of benthic chlorophyll by $27 \%$. Mean density of the total macrobenthic fauna was $62 \%$ lower in shaded ponds relative to controls. This condition persisted over the 2 mo study and showed little change in magnitude during the experiment, suggesting a lower 'carrying capacity' in the shaded habitat instead of a transient effect. Shading caused little change in community composition and had no effect on Shannon's index of diversity. Of the 5 most abundant taxa, midge larvae (Chironomus sp.) and the polychaetes Laeonereis culveri and Hobsonia florida densities were significantly lower in shaded ponds. All 3 are known to feed on benthic microalgae. The other 2 dominants, hydrobiid snails and the oligochaete Paranais litoralis, were not significantly affected by shading. Because shading reduced dissolved oxygen levels as well as benthic microalgae, half-way through the experiment continuous aeration was started in 2 of the shaded and 2 of the unshaded ponds in order to maintain high oxygen levels. Oxygenation had no effect on total macrofaunal density, the density of any individual taxon, or species diversity. Results of this manipulative field experiment implicate microalgae as a limiting resource of this macrofaunal community.
\end{abstract}

KEY WORDS: Saltmarsh $\cdot$ Pond $\cdot$ Benthic macrofauna $\cdot$ Food limitation $\cdot$ Microalgae $\cdot$ Microphytobenthos $\cdot$ Recolonization

\section{INTRODUCTION}

Multiple factors have been shown to affect benthic macrofaunal communities in unconsolidated sediments, including predation (Peterson 1979, Kneib 1984) and disturbance (Rhoads et al. 1978; review by Hall et al. 1992). Though competition has been difficult to demonstrate (Peterson 1979), there is growing evidence that food limitation impacts benthic macrofau-

${ }^{*}$ Present address: UC San Diego, San Diego Supercomputer Center, MC0505, 9500 Gilman Drive, La Jolla, California 92093-0505, USA. E-mail: kstocks@sdsc.edu nal communities in these habitats. Results of many field studies have demonstrated correlations between population size, growth and/or reproductive output with measures of food resources in the sediments either spatially (e.g., Weinberg 1979, Levinton \& Bianchi 1981, Whitlatch 1981) or temporally (e.g., Weinberg 1979, Whitlatch 1980, Marsh \& Tenore 1990, Trueblood et al. 1994). Laboratory experiments have shown decreased growth, numbers and/or reproductive output with decreased food levels (e.g., Tenore \& Chesney 1985, Levin \& Creed 1986, Zajac 1986, Grémare et al. 1989, Forbes \& Lopez 1990). Studies in which food competition is inferred from changes in 
macrofaunal density have shown similar impacts both in the laboratory (Fenchel \& Kofoed 1976, Levinton \& Bianchi 1981) and the field (Stiven \& Kuenzler 1979, Cheng et al. 1993). The few studies explicitly manipulating food levels in sediments in situ and following recolonization patterns all found increased numbers of benthic macrofauna with higher food levels (Grassle et al. 1985: estuarine subtidal mesocosms; Snelgrove et al. 1992: deep sea; Hentschel \& Jumars 1994: intertidal sandflat; Renaud et al. 1999: continental shelf). While the absolute importance of food limitation is still debatable, recent reviews have concluded that: 'At large scales, food may be the primary limiting factor for benthic biomass' (Herman et al. 1999); and that 'there is abundant support in the literature for the position that food supply to the benthos plays a fundamentally important role in determining most of the biological properties of benthic infaunal communities' (Olafsson et al. 1994).

While the relative importance of different sediment components (e.g., detritus, bacteria, microalgae, fungi) ingested by deposit feeders is actively debated (Lopez \& Levinton 1987), several lines of evidence suggest that benthic microalgae, and diatoms in particular, are primary food resources in shallow coastal areas (Trueblood et al. 1994; review by Miller et al. 1996). In addition to studies on the importance of diatoms in the diets of particular species (e.g., Mazurkiewicz 1975, Fenchel \& Kofoed 1976), multiple stable isotope analyses of estuarine systems consistently show that microalgae are a likely major carbon source for higher trophic levels (Peterson et al. 1986, Peterson \& Howarth 1987, Sullivan \& Moncreiff 1990, Currin et al. 1995, Middelburg et al. 2000). One study experimentally increasing benthic microalgal biomass through nutrient additions found corresponding increases in herbivorous macrofauna, although predation also had an effect (Posey et al. 2000).

The present study tested whether microalgal resource levels can affect the rate or nature of benthic macrofaunal recolonization into a saltmarsh habitat. The study units were in situ mesocosms mimicking natural saltmarsh ponds, which are common features in the vegetated intertidal zone of saltmarshes in the eastern USA. The method used to decrease microalgae was shading over the mesocosms. The pond mesocosms were started with defaunated sediment, and the colonizing benthic community was compared in shaded and unshaded mesocosms. This approach allowed the study to have several desired characteristics. First, the scale of the recolonization-an entire pond-matched the scale of known natural disturbances in ponds (e.g. anoxia, extreme temperature or salinity shifts and desiccation). Second, the shading could be applied to a whole pond to create a persistent change in the hypothesized food resource (i.e. in contrast to following recolonization after a one-time food addition to sediments). Finally, the factor manipulated, light, is thought to be the main limiting factor of primary productivity in shallow and intertidal estuarine habitats (reviews by Heip et al. 1995, MacIntyre et al. 1996, Underwood \& Kromkamp 1999). It is also a factor that varies naturally among marsh ponds due to water depth, turbidity, shading from submerged aquatic vegetation or overhanging marsh vegetation and, on a larger scale, latitude and cloud cover.

\section{MATERIALS AND METHODS}

Mesocosm and site description. This study was conducted in a fringing saltmarsh in the Hackensack Meadowlands area of New Jersey, USA $\left(40.7844^{\circ} \mathrm{N}\right.$, $74.1247^{\circ} \mathrm{W}$ ). The mesocosms were placed in a narrow ( $10 \mathrm{~m}$ wide) vegetated intertidal area dominated by Spartina alterniflora; offshore of this zone was an extensive mudflat. Salinity was generally between 10 and 15 , and tidal range was $\sim 1.5 \mathrm{~m}$.

The present study used in situ mesocosms mimicking natural saltmarsh ponds to avoid the high variability in natural pond communities caused by different diameters, depths, intertidal levels, sediment types and disturbance histories. The mesocosms were cylindrical plastic tanks $\sim 1.4 \mathrm{~m}$ in diameter and $\sim 0.6 \mathrm{~m}$ deep (Fig. 1A). This is at the lower end of the size range of natural ponds (K. I. Stocks pers. obs.). Tanks were soaked in water for at least $48 \mathrm{~h}$ and rinsed thoroughly before deployment. Eight tanks were emplaced in the vegetated marsh zone in a line parallel with the shore. Each tank was dug into the sediment until the lip was approximately $15 \mathrm{~cm}$ above the surrounding marsh surface; burying the tanks flush with the surrounding sediment was not feasible because the shallow water table at low tide made sediments below a certain depth unstable and tank installation difficult. To create a smooth incline between the pond edges and the surrounding marsh surface and to prevent erosion around the tank edge, each tank was surrounded by a 0.6 to $1.0 \mathrm{~m}$ wide skirt of landscaping erosion-control cloth over a stiff wire mesh (Fig.1B). Although ponds were slightly elevated from the sediments immediately surrounding them, they were still within the intertidal range of the Spartina alterniflora zone with flooding frequencies similar to those observed in the natural marsh ponds of the Delaware National Estuarine Research Reserve (Stocks 2000) and the Jacques Cousteau Estuarine Research Reserve in New Jersey (Stocks 2000). Because the physical structure of $S$. alterniflora plants naturally inhibits bedload transport, and because natural marshes have topographic varia- 

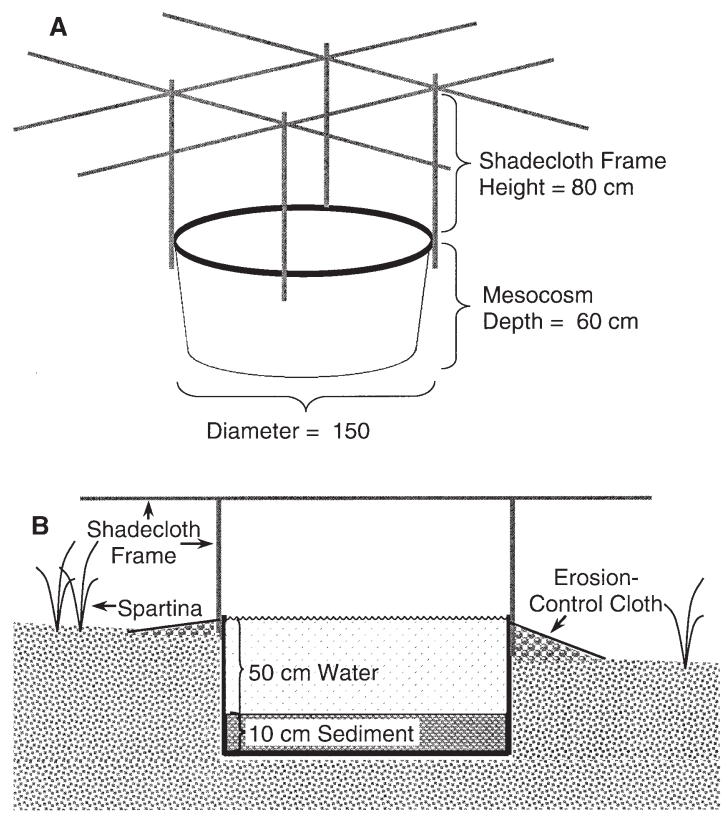

Fig. 1. Diagrams of saltmarsh pond mesocosms. (A) Tank and shadecloth apparatus dimensions; shadecloth, not shown, was placed horizontally atop the frame. (B) Side cross-section of a mesocosm installed in the intertidal marsh zone (shown at low tide)

tions, the gentle slope to the pond edges was not expected to alter macrofaunal transport substantially. The only physical artifacts known to affect water flow (and presumably macrofaunal transport) caused by using mesocosms instead of natural ponds, were the landscaping skirt, 4 vertical aluminum posts $(2.5 \mathrm{~cm}$ diameter) holding up the shade cloth, and blockage of any potential groundwater flow.

The ponds created by the tanks were intertidal and matched for inundation time. At low tide, they were isolated bodies of standing water. Diurnal tidal waters flooded and covered the ponds for $\sim 3 \mathrm{~h}$ during every high tide.

The purpose of this $60 \mathrm{~d}$ study was to examine recolonization processes of benthic macrofauna. Although some macrofaunal communities have been shown to return to ambient community structure in this period (Dauer \& Simon 1976, Zajac \& Whitlatch 1982, Smith \& Brumsickle 1989), this study was not designed to predict the 'climax' or equilibrium community (if such exists).

Shading treatment. To create the desired treatment effect, 4 ponds had shadecloth suspended above them to reduce incoming sunlight and, as a control, 4 ponds had a fine $2.5 \mathrm{~cm}$ mesh netting that did not perceptibly impact incoming sunlight (Fig. 1B). Readings with a Li-cor Li-1000 light meter indicated that the shading treatment reduced light in the shaded ponds by $92 \%$ compared to the control ponds.
The experiment was initiated on June 16, 1997 (Day 0), when all the ponds were emptied and sponged and rinsed thoroughly to remove all water and sediment. A $10 \mathrm{~cm}$ layer of defaunated sediment was then added to the bottom of each pond. This sediment had been collected from the adjoining mudflat (by weight, $90 \%$ fines $<63 \mu \mathrm{m}$ ) and sealed in plastic for 2 to $3 \mathrm{wk}$ to create anoxic conditions. Eight samples of this mud were examined for benthic macrofauna and yielded 1 intact individual, indicating 99.6\% defaunation. Ponds were flooded by the incoming tide and were allowed to recolonize naturally.

Pond conditions. Dissolved oxygen (DO) at $10 \mathrm{~cm}$ above the bottom was measured in the ponds using a YSI Model 57 oxygen meter, corrected for salinity as measured by a refractometer. A $24 \mathrm{~h}$ sampling run was conducted on Day 22 (August 7), during which DO was measured in each pond every $2 \mathrm{~h}$. In addition, DO was measured near mid-day and just pre-dawn on multiple occasions.

The dawn-dusk-dawn DO readings from the $24 \mathrm{~h}$ sampling were used to estimate gross primary production in the mesocosms (Odum \& Hoskin 1958). The daily respiration rate (autotrophic plus heterotrophic) was taken as the average decrease in oxygen per hour during the $10 \mathrm{~h}$ night and extrapolated to a $24 \mathrm{~h}$ day. The daily gross primary production (GPP) was calculated by adding the average hourly increase in oxygen during the day to the hourly respiration rate calculated from the night and extrapolating to a $14 \mathrm{~h}$ day. Both measures were adjusted for diffusive exchange by subtracting the diffusive flux, as calculated by $k \times$ (pond $\mathrm{O}_{2}-\mathrm{O}_{2}$ saturation). Since the true piston velocity $(k)$ was not known, calculations were done with 3 values: $0.1,0.05$ and $0.01 \mathrm{~m} \mathrm{~s}^{-1}$. These span the range between average values from natural systems in low wind (Marino \& Howarth 1993) and similarly-sized, indoor mesocosms (Peterson et al. 1997). Temperaturespecific oxygen saturation values were taken from Libes (1992).

The drawbacks of this method are that it cannot separate benthic from pelagic production/respiration, assumes heterotrophic and autotrophic respiration rates are constant over $24 \mathrm{~h}$, and requires assumptions about air-water gas exchange that may not be met in ponds covered by tidal waters at high tide. Although the effect of the flooding tide is not accounted for, casual observation of profiles taken during high tides showed that the ponds generally retained their oxygen and temperature signatures during the flood and ebb, indicating little mixing. Potentially increased atmospheric flux due to ponds bubbling during periods of supersaturation was also not accounted for.

Overall, the GPP values should be viewed as relative measures. They are intended only to aid in the inter- 
pretation of the substantial lowering of oxygen levels in shaded ponds by indicating the general magnitude of the production decrease needed to account for the oxygen differential. Light and dark in situ incubations were attempted but necessitated disturbing too much bottom surface to replicate sufficiently.

Salinity readings were taken by refractometer in each pond in conjunction with all benthic sampling and oxygen sampling. One max.-min. thermometer was hung in each pond, and maximum, minimum and current temperatures were recorded; and the thermometer was then re-set during all pond visits.

Because there were no natural ponds in this particular fringing marsh it was not possible to sample a truly comparable ambient community (the choice of study site was prescribed by the funding source). The marsh was adjacent to a large mudflat, which was presumed to be a source of colonizing macrofauna. Samples of the mudflat macrofauna were taken with cores as described for the ponds on 2 dates, corresponding to Days 12 and 62 of the experiment.

Sampling Days 4 to 39. At 4, 13, 20, 27 and $35 \mathrm{~d}$ after initiation, 4 cores, each $3.8 \mathrm{~cm}$ in diameter and $>8 \mathrm{~cm}$ deep, were taken from each pond to assess benthic chlorophyll (except on Day 35 when poor weather only allowed time for 2 cores per pond). The sampling was stratified so that half the cores were taken from the outer $50 \%$ of the pond area, near the walls, and half from the center $50 \%$ of the ponds. A sampling frame with $10 \mathrm{~cm}$ grid squares was used to randomize core placement and ensure that cores were never taken twice from the same square. The top $1 \mathrm{~cm}$ of each core was placed in a jar, immediately wrapped in aluminum foil, stored on ice, and frozen within $6 \mathrm{~h}$. Samples were later extracted in $90 \%$ acetone and analyzed for chlorophyll on a Beckman DU-64 spectrophotometer. Chlorophyll a estimates were corrected for phaeopigments by using acidification (Parsons et al. 1984).

On Days 4, 20 and 35, the ponds were sampled for benthic macrofauna using cores identical to those used in the chlorophyll sampling except that the top $5 \mathrm{~cm}$ of each core was preserved in buffered $4 \%$ formaldehyde. After a minimum of $24 \mathrm{~h}$, the samples were rinsed over a $300 \mu \mathrm{m}$ sieve and transferred to $70 \%$ ethanol containing Rose Bengal stain. The samples were later examined under a dissecting microscope and all macrofauna identified and counted. Predominately epibenthic or meiofaunal taxa, including numerous copepods and nematodes, were not included in the study. Fishes and larger crustaceans were frequently observed in the ponds but were not sampled.

Filamentous green periphyton had a tendency to grow on the pond walls. Because this is not a normal feature of natural marsh ponds, and because unchecked periphyton growth can greatly change the productivity of a mesocosm (Chen et al. 1997), the pond walls were frequently scraped and periphyton carefully collected and removed to prevent the accumulation of any substantial biomass.

Sampling Days 39 to 60: oxygen and shading treatments. On Day 39 after initiation, the experimental design was changed because oxygen levels were persistently depressed in shaded ponds and this condition was not ameliorated by the unexpectedly minimal mixing that occurred during tidal inundation (see 'Results'). Two of the unshaded ponds and 2 of the shaded ponds were bubbled continuously with air using an air compressor, plastic tubing, and airstones suspended from the shade frame. The purpose of this modification was to identify shading impacts due to oxygen stress on the macrofauna. The ponds were not restarted with azoic sediment; macrofauna and chlorophyll were sampled on Days 42, 50, and 60 after initiation.

Statistics. Data were analyzed separately for Days 4 to 35 , when shading was the only treatment, and for Days 42 to 60 , when oxygenation was included in the experimental design. For Days 4 to 35 , treatment effects on chlorophyll concentrations, macrofaunal densities, diversity, and evenness were tested with 2 -factor, repeated-measures ANOVAs, with time (sampling date) and shading treatment as factors (Zar 1999). Ponds were considered replicates, and the 4 cores taken per pond were averaged to provide a single observation per pond. The resulting model was: $Y_{i j k}=\mu+S_{i}+D_{j}+S D_{i j}+p(S)_{k(i)}+D p(S)_{j k(i)}+\varepsilon_{i j k}$ where $\mu$ was the grand mean, $S$ the shading treatment, $D$ the sampling date (time effect), and $p$ the pond. After Day 39, when the oxygenation treatment began, a 3-factor repeated measures ANOVA tested for treatment effects; shading and oxygenation were 'between' factors, date was a 'within' factor, and ponds were replicates (Zar 1999). When data did not meet assumptions of normality and equality of variance, transformations were employed as noted in 'Results' - in all cases transformed data conformed with test assumptions.

Unpaired 2-tailed $t$-tests were used to compare pairs of means (Zar 1999). If necessary, data were transformed as noted to meet test assumptions or, if transformations were not successful, Mann-Whitney ranksum tests were applied. 'Significant' and 'highly significant' are used to denote statistical significance at $0.01<\mathrm{p}<0.05$ and $\mathrm{p}<0.01$ respectively. All ANOVA and means tests were done using Prophet 5.0 software (MarketMiner Inc., Charlottesville).

Ordination was used to assess the similarity of community structure among samples. Specifically, principal components analysis of hypergeometric probabilities (PCA-H) was applied as described by Trueblood et al. (1994). This method is similar to nonmetric multi- 
dimensional scaling and has the advantage that the original species axes can be overlaid onto the ordination as a Gabriel biplot to show which species are primarily responsible for patterns found in sample ordination. The more important a species is in creating differences between samples, the longer its vector appears on the biplot. The smaller the angle between a species vector and a PCA-H axis, the more closely that species is correlated with that axis-vectors that are almost parallel to an axis are very strongly correlated with it. All ordination analyses were conducted with a random draw size of 10 individuals on Matlab 5.2 software using routines provided by Gene Gallagher at the University of Massachusetts, Boston (available at http://www.es.umb.edu/edgwebp.htm). Community diversity and evenness were calculated using the Shannon-Wiener index of diversity $\left(H^{\prime}\right)$ und Pielou's index of evennes $(J)$ (natural logarithm base) (Pielou 1969).

\section{RESULTS}

\section{Salinity and temperature}

Shading had no effect on salinity (a p-value could not be calculated since shaded and unshaded values were usually identical). Maximum temperatures in the shaded ponds were on average $1.9^{\circ} \mathrm{C}$ cooler than unshaded ponds $(p<0.01)$; minimum temperatures were unaffected by shading $(\mathrm{p}=0.93)$.

\section{Oxygen levels}

Diel dissolved oxygen patterns differed substantially between shaded and unshaded ponds before oxygenation commenced. Over a $24 \mathrm{~h}$ sampling period, in unshaded ponds DO increased during daylight hours

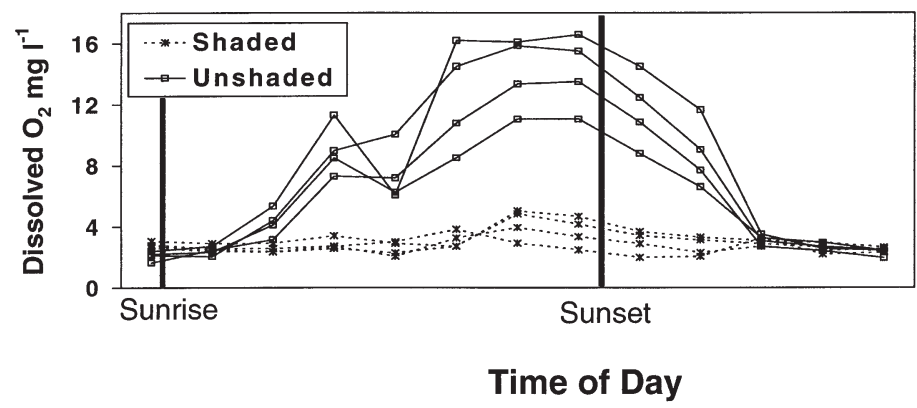

Fig. 2. Diel pattern of dissolved oxygen levels from August 7 and 8. Each line represents 1 pond mesocosm then decreased overnight to a low near dawn; in shaded ponds DO levels were low at all times (Fig. 2). Average mid-day DO levels were $3.7 \mathrm{mg} \mathrm{l}^{-1}$ for shaded ponds and $13.0 \mathrm{mg} \mathrm{l}^{-1}$ (supersaturated) for unshaded ponds. Average dawn DO levels were consistently lower in unshaded than shaded ponds ( 2.1 to 2.6 vs 2.5 to $3.0 \mathrm{mg} \mathrm{l}^{-1}$ respectively), although this difference was statistically significant on only 1 of 3 days measured (Mann-Whitney rank-sum test). Values $<2 \mathrm{mg} \mathrm{l}^{-1}$ were recorded in individual ponds on several dates; the lowest value was $0.75 \mathrm{mg} \mathrm{l}^{-1}$ in an unshaded pond.

The oxygenation treatment started on Day 39 was effective: all aerated ponds had dissolved oxygen levels $>4 \mathrm{mg} \mathrm{l}^{-1}$ at all times measured $(\mathrm{n}=9)$, and were usually $>5 \mathrm{mg} \mathrm{l}^{-1}$. In unaerated ponds, DO patterns were similar to the pre-aeration period, and reached lows of 1.3 to $3.9 \mathrm{mg} \mathrm{l}^{-1}$ in shaded ponds and 1.3 to $3.2 \mathrm{mg} \mathrm{l}^{-1}$ in unshaded ponds at dawn.

\section{Chlorophyll}

On all 8 sampling dates, the standing stocks of chlorophyll were lower in the shaded than in the unshaded ponds (Table 1). For Days 4 to 39 (before oxygenation began), the amount of chlorophyll $a$ in sediments of the shaded treatment average $27 \%$ less than in the control, and this effect was highly significant (Fig. 3, Table 1). There were also highly significant differences between sampling days, but full standing stocks appear to have been established by Day 4, and there was no indication of a directed trend over time. After the oxygenation treatment began on Day 39, the shaded ponds continued to have highly significant lower benthic chlorophyll stocks in comparison with the unshaded ponds, with an average reduction of $43 \%$ (Fig. 3). The oxygenation treatment was not a significant factor, nor was time or 
Table 1. ANOVA results for main effects (see 'Materials and methods' for statistical details). * significant at $\mathrm{p}<0.05 ;{ }^{* *}$ highly significant at $\mathrm{p}<0.01$. Shading and oxygenation each had $1 \mathrm{df}$; date has 2 for all tests except chlorophyll, which has 4

\begin{tabular}{|c|c|c|c|c|c|c|}
\hline \multirow{2}{*}{ Factor } & \multicolumn{2}{|c|}{ Shading } & \multicolumn{2}{|c|}{ Date } & \multicolumn{2}{|c|}{ Oxygenation } \\
\hline & $F$ & $\mathrm{p}$ & $F$ & $\mathrm{p}$ & $F$ & $\mathrm{p}$ \\
\hline \multicolumn{7}{|l|}{ Days 4 to 35} \\
\hline Chlorophyll & 14.58 & $0.009^{* *}$ & 7.48 & $0.005^{* *}$ & & \\
\hline \multicolumn{7}{|l|}{ Abundances: } \\
\hline Total $^{\mathrm{a}}$ & 25.63 & $0.002^{* *}$ & 28.38 & $<0.001^{* *}$ & & \\
\hline Laeonereis culveri & 25.74 & $<0.001^{* *}$ & 7.21 & $0.013^{* *}$ & & \\
\hline Hobsonia florida ${ }^{\mathrm{b}}$ & 36.02 & $0.002^{* *}$ & 4.59 & $0.042^{*}$ & & \\
\hline Chironomus sp. & 18.50 & $0.002^{* *}$ & 10.35 & $0.005^{* *}$ & & \\
\hline Hydrobiidae sp. $^{a}$ & $<0.01$ & 0.964 & 27.57 & $<0.001^{* *}$ & & \\
\hline Diversity $\left(H^{\prime}\right)$ & $<0.01$ & 0.928 & 0.06 & 0.267 & & \\
\hline Evenness $(J)$ & 14.59 & $0.009^{* *}$ & 2.22 & 0.152 & & \\
\hline \multicolumn{7}{|l|}{ Days 42 to 60} \\
\hline Chlorophyll & 12.89 & $0.023^{*}$ & 3.36 & 0.087 & 0.05 & 0.835 \\
\hline Total abundance & 26.38 & $0.007^{* *}$ & 0.93 & 0.434 & 3.36 & 0.140 \\
\hline Diversity $\left(H^{\prime}\right)$ & 4.52 & 0.100 & 6.68 & $0.020^{*}$ & 0.28 & 0.627 \\
\hline Evenness $(J)$ & 5.63 & 0.077 & 0.75 & 0.501 & 0.61 & 0.479 \\
\hline
\end{tabular}

Table 2. Average number of individuals per $11.4 \mathrm{~cm}^{2}$ core for all macrofaunal taxa representing $>3 \%$ of individuals on any sampling date. Values are averages of all replicate cores and ponds within a given treatment. Y: treatment was applied; N: no manipulation (control); Day 0: June 16. Pol: polychaete; Gast: gastropod; Dipt: dipteran; Olig: oligochaete; Ane: anemone

\begin{tabular}{|c|c|c|c|c|c|c|c|c|c|c|c|}
\hline 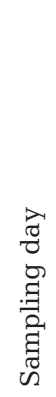 & 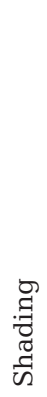 & $\begin{array}{l}\text { : } \\
\stackrel{0}{0} \\
0 \\
0 \\
0 \\
0 \\
0 \\
0 \\
0\end{array}$ & 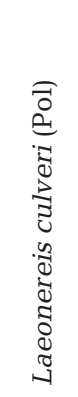 & 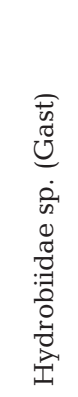 & 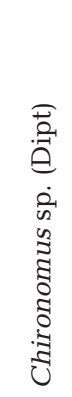 & 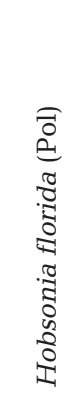 & 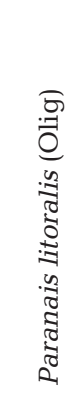 & 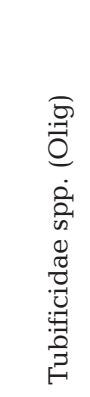 & 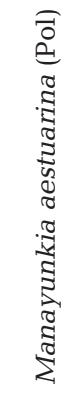 & 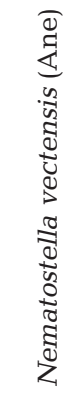 & 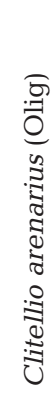 \\
\hline \multicolumn{12}{|c|}{ Experimental tanks } \\
\hline 4 & $\mathrm{Y}$ & $\mathrm{N}$ & 4.3 & 2.0 & 7.0 & 0.5 & 0.8 & 0.8 & 0.5 & 0.5 & 0.0 \\
\hline 4 & $\mathrm{~N}$ & $\mathrm{~N}$ & 26.3 & 2.8 & 13.5 & 3.8 & 0.3 & 2.3 & 0.5 & 2.8 & 0.3 \\
\hline 20 & $\mathrm{Y}$ & $\mathrm{N}$ & 12.8 & 17.0 & 12.8 & 3.3 & 0.0 & 0.5 & 0.0 & 0.0 & 0.0 \\
\hline 20 & $\mathrm{~N}$ & $\mathrm{~N}$ & 71.3 & 11.3 & 38.3 & 35.3 & 0.3 & 3.0 & 0.3 & 0.0 & 0.8 \\
\hline 35 & $\mathrm{Y}$ & $\mathrm{N}$ & 21.0 & 8.8 & 9.3 & 5.0 & 1.8 & 0.8 & 0.5 & 0.0 & 0.5 \\
\hline 35 & $\mathrm{~N}$ & $\mathrm{~N}$ & 59.3 & 9.8 & 13.5 & 12.8 & 0.3 & 1.5 & 1.3 & 0.0 & 0.8 \\
\hline 42 & $\mathrm{Y}$ & $\mathrm{N}$ & 31.5 & 12.5 & 10.5 & 7.5 & 2.0 & 0.5 & 0.5 & 0.5 & 0.5 \\
\hline 42 & $\mathrm{Y}$ & $\mathrm{Y}$ & 23.0 & 9.5 & 7.5 & 9.5 & 0.5 & 1.5 & 0.0 & 0.0 & 1.0 \\
\hline 42 & $\mathrm{~N}$ & $\mathrm{~N}$ & 73.5 & 17.5 & 10.5 & 12.5 & 1.0 & 1.0 & 0.0 & 0.0 & 2.0 \\
\hline 42 & $\mathrm{~N}$ & $\mathrm{Y}$ & 80.5 & 23.0 & 17.5 & 21.5 & 7.0 & 0.5 & 0.5 & 0.0 & 0.0 \\
\hline 50 & $\mathrm{Y}$ & $\mathrm{N}$ & 23.5 & 20.5 & 7.5 & 7.0 & 2.5 & 1.0 & 0.0 & 0.0 & 0.5 \\
\hline 50 & $\mathrm{Y}$ & $\mathrm{Y}$ & 31.0 & 7.0 & 5.5 & 22.0 & 9.5 & 1.0 & 0.5 & 0.0 & 0.0 \\
\hline 50 & $\mathrm{~N}$ & $\mathrm{~N}$ & 81.5 & 26.5 & 11.0 & 21.0 & 7.5 & 1.5 & 1.0 & 0.0 & 1.5 \\
\hline 50 & $\mathrm{~N}$ & $\mathrm{Y}$ & 71.5 & 33.5 & 19.5 & 21.0 & 40.0 & 2.5 & 0.5 & 0.0 & 1.0 \\
\hline 60 & $\mathrm{Y}$ & $\mathrm{N}$ & 14.5 & 17.5 & 3.0 & 4.5 & 9.0 & 1.5 & 1.0 & 0.5 & 1.5 \\
\hline 60 & $\mathrm{Y}$ & $\mathrm{Y}$ & 19.0 & 18.5 & 5.0 & 22.0 & 46.5 & 1.0 & 1.0 & 0.0 & 0.0 \\
\hline 60 & $\mathrm{~N}$ & $\mathrm{~N}$ & 49.0 & 18.5 & 4.0 & 9.0 & 24.5 & 4.0 & 0.0 & 0.0 & 0.5 \\
\hline 60 & $\mathrm{~N}$ & $\mathrm{Y}$ & 43.5 & 24.5 & 15.5 & 8.0 & 66.0 & 3.0 & 0.0 & 0.0 & 0.0 \\
\hline \multicolumn{12}{|c|}{ Ambient mudflat } \\
\hline 12 & & & 46.5 & 6.4 & 0.3 & 17.9 & 0.0 & 113.0 & 40.6 & 29.8 & 6.4 \\
\hline 62 & & & 15.6 & 0.8 & 0.4 & 0.8 & 0.0 & 66.6 & 10.2 & 13.8 & 6.8 \\
\hline
\end{tabular}


any interaction (Table 1). No macroalgae or aquatic vegetation grew in the ponds except for a filamentous green alga growing on the pond sides, which was removed.

\section{Photosynthesis}

Calculations from the daily change in oxygen levels indicated a substantial effect of shading on whole-pond gross primary production regardless of piston velocity used to calculate diffusive flux. GPP averages for the 4 unshaded ponds ranged between 13.2 and $13.4 \mathrm{~g} \mathrm{O}_{2} \mathrm{~m}^{-2} \mathrm{~d}^{-1}$ while the shaded ponds ranged between 1.21 and $1.37 \mathrm{~g} \mathrm{O}_{2} \mathrm{~m}^{-2} \mathrm{~d}^{-1}$, depending on the $\kappa$ value used.

\section{Macrofaunal community composition}

A fairly simple benthic macrofaunal community colonized the ponds: 4 taxa comprised $>90 \%$ of individuals during Days 4 to 42 (Table 2). These were, in order of overall abundance, the nereid polychaete Laeonereis culveri, midge larvae of the genus Chironomus, juvenile hydrobiid gastropods, and the ampharetid polychaete Hobsonia florida. The midge larvae could only be identified to genus and the small gastropods could only be identified to family, but both groups appeared to be represented by a single species. During the last 2 sampling dates, Days 50 and 60, a fifth species, the naidid oligochaete Paranais litoralis, became abundant. A total of 24 taxa were collected during the experiment, but no other taxon composed over $3 \%$ of the individuals collected on any date.

Ordination plots show that the main factor relating to variation in community structure among samples was time: samples were distributed along the first and second principal components axes in an arc according to sampling date (Fig. 4A-C), and these axes accounted for 58 and $17 \%$ of the sample variation respectively. A Gabriel Euclidean distance biplot showed that the trend was mainly accounted for by the presence of Paranais litoralis late in the experiment, with some effect from an increase in Hobsonia florida after Day 4 (Fig. 4D). Neither shading nor oxygenation factored in the first 2 principal axes. A shading effect was seen in the third axis (accounting for just $13 \%$ of the variance), but the biplot (not shown) indicated that the pattern was driven by the single taxon Hydrobiidae.

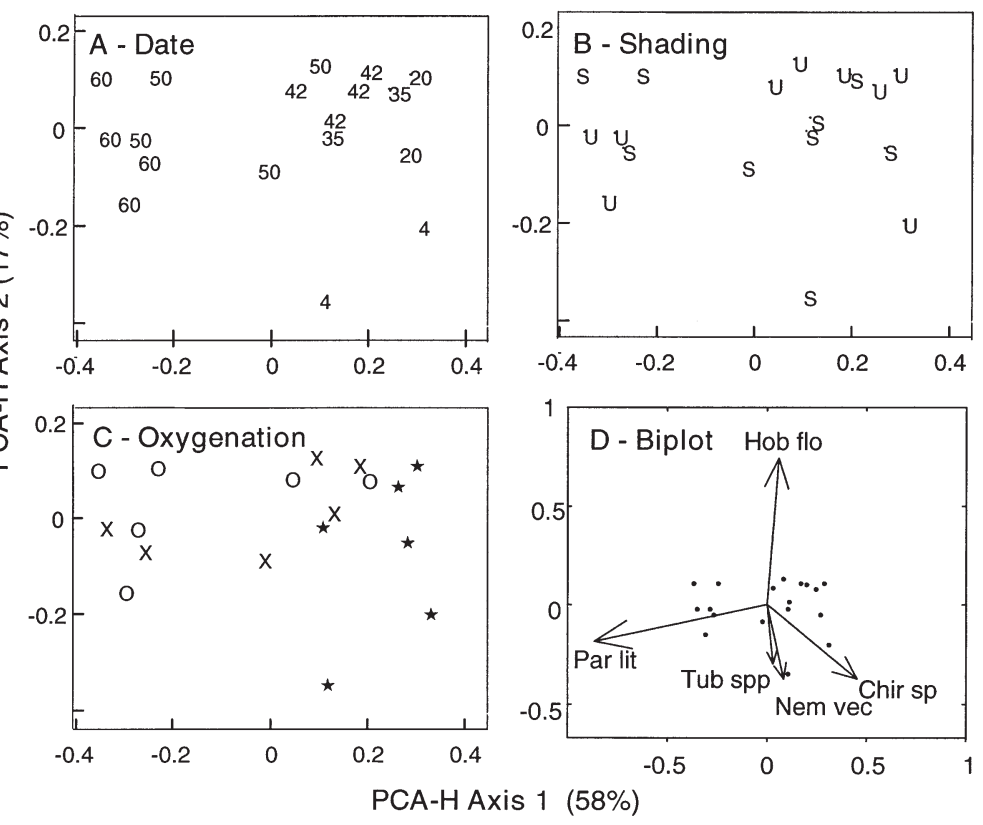

Fig. 4. Principal components analysis using hypergeometric probabilities of mesocosm macrofaunal communities by date and treatment. All replicates and ponds within a given treatment are combined. (A) Date effects (numbers = days since experiments began). (B) Shading effect (s: shaded pond mesocosms; U: unshaded). (C) Oxygen effect (O: oxyenated ponds; $\mathrm{x}$ : unoxygenated; $\star$ : sample taken before oxygenation began). (D) Gabriel Euclidian distance biplot of mesocosm communities howing axis vectors for species accounting for $>2 \%$ of sample variance overlaid onto the original PCA-H plot (note that axis scaling differs in D); Hob flo: Hobsonia florida; Par lit: Paranais litoralis; Tub spp: Tubificidae pp.; Nem vec: Nematostella vectensis; Chir sp: larval Chironomus sp.

\section{Macrofaunal density}

The average density of total macrofauna was lower in the shaded treatment on each of the 3 dates sampled before oxygenation began (Days 4, 20 and 35: Fig. 5). For these dates, the density of macrofauna in the shaded ponds was $62 \%$ lower than in controls, and this difference was statistically significant $(p<0.01$; Table 1). Sampling date was also a significant factor $(p<0.01)$, because densities in both shaded and unshaded ponds increased through time.

Of the 4 most common taxa, 3 showed significant differences in density with shading for Days 4 to 35 (Fig. 6, Table 1): the populations of the polychaetes Laeonereis culveri and Hobsonia florida and Chironomus midge larvae were, respectively, 77, 84 and 52\% lower in shaded ponds. The fourth most abundant taxon, juvenile hydrobiid gastropods, showed no response to shading. Although snail densities were unaffected by shading, all other abundant taxa were lower in shaded ponds and consequently the hydrobiids represented a larger proportion of the community in shaded than unshaded ponds. This is responsible for 


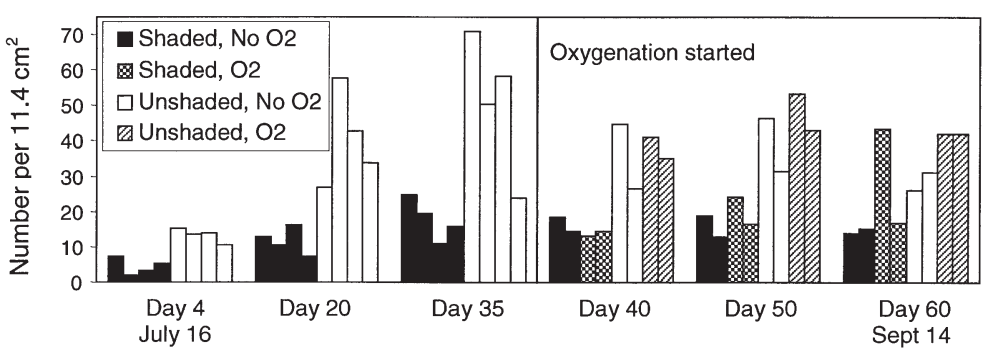

Fig. 5. Number of total macroinfaunal individuals. Each bar represents average of 4 replicate cores taken within a pond mesocosm. Initially, 4 ponds were shaded to reduce primary production and 4 were unshaded. Starting between Days 35 and 42, 2 shaded ponds and 2 unshaded ponds were constantly bubbled with air to prevent hypoxia. Shading had a highly significant effect on abundance both before and after oxygenation; oxygenation had no significant effect (Table 1)

the slight shading effect detected in the third PCA-H axis. For all 4 taxa, time was also a significant factor and densities increased over time.

Tests on data from after the oxygenation treatment began (Day 39) indicate that oxygenation did not have a significant effect on total macrofaunal density, but shading continued to be associated with lowered macrofaunal densities (Table 1, Figs 5 \& 6). Date was not a significant factor, nor was any interaction term. Because statistical power was low $(n=2)$ for treatment effects once oxygenation began, and because many of the data for individual taxa had non-normal distributions requiring non-parametric testing, significant effects on individual taxa were rare. However, the same species-specific trends found in Days 4 to 35 continued. The late-arriving oligochaete species, Paranais litoralis, showed no significant response to either shading or oxygenation.

\section{Diversity and evenness}

There was no significant effect of shading on the diversity of the community as measured by $H^{\prime}$ (both averaged 1.5 ); sampling day was highly significant, but followed no directed trend over time (Table 1). There was a highly significant shading effect on species evenness as measured by $J$ (Table 1): the shaded ponds averaged $14 \%$ higher evenness than the unshaded ponds $(0.77$ vs 0.68$)$. There was neither a significant date effect nor any consistent trend in the strength of the shading effect on evenness, which neither increased nor decreased over time.

\section{Ambient mudflat community}

All the common taxa in the ponds were found in the ambient mudflat community, however only Laeonereis culveri and Hobsonia florida were common (over $3 \%$ of total numbers on a sampling date) in the mudflat (Table 2). Several taxa that were common in the mudflat were absent or rare in the ponds, including a group of tubificid oligochaete species, the sabellid polychaete Manayunkia aestuarina, and the burrowing edwardsiid anemone Nematostella vectensis.

\section{DISCUSSION}

A shading effect was clearly found in the benthic macrofauna: total densities of macrofauna were $62 \%$ lower in shaded ponds during Days 4 to 35 , and this effect was highly significant (Table 1, Fig. 5). This shading effect persisted throughout the experiment. Both shaded and unshaded ponds reached maxima in total densities on or before Day 35, and there-

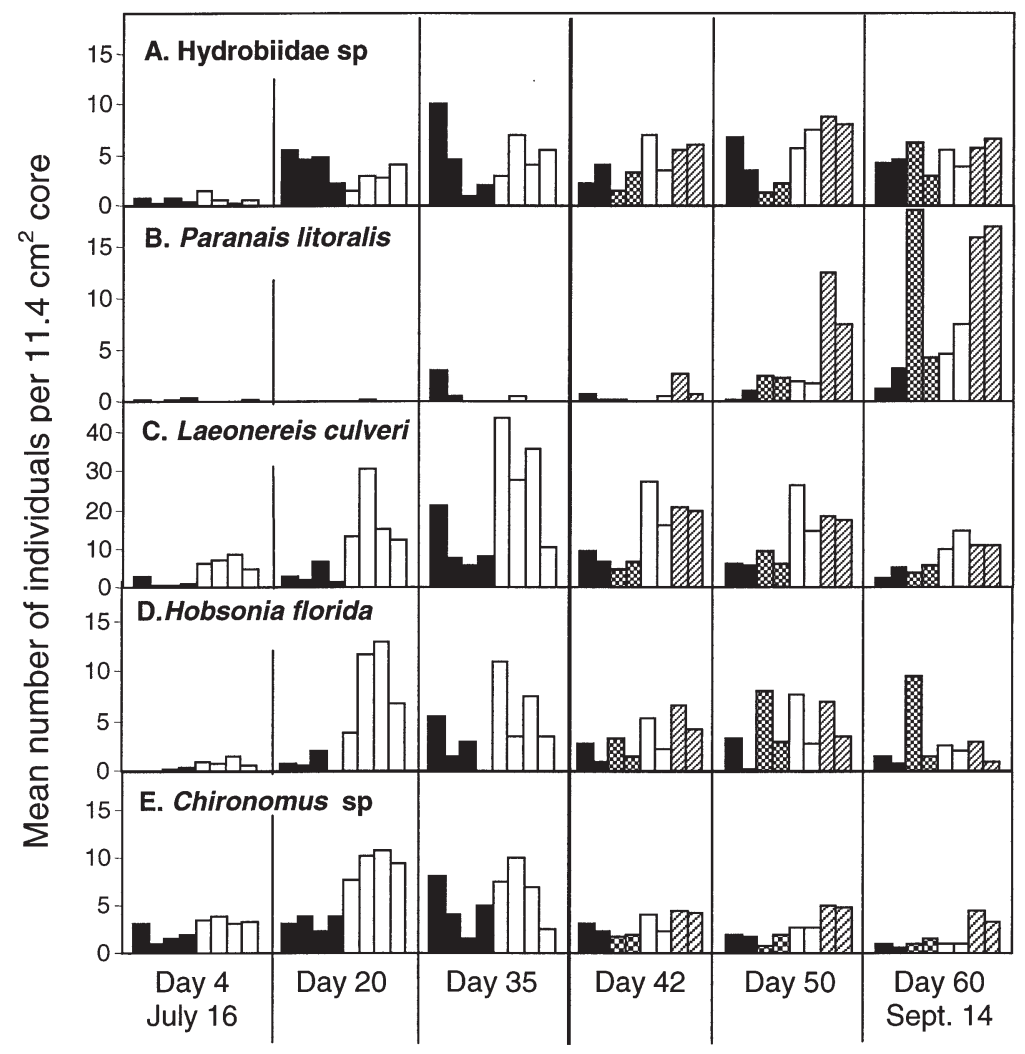

Shaded, No O2 8 Shaded, O2 $\square$ Unshaded, No O2 $\square$ Unshaded, O2

Fig. 6. Mean densities of dominant macrofaunal taxa as a function of sampling date. Each bar represents mean of replicate cores taken per pond mesocosm 
after the difference in macrofaunal densitities between shaded and unshaded ponds remained relatively constant (Fig. 5). Although $60 \mathrm{~d}$ is not necessarily long enough to reach a climax community (if such exists) in this habitat, 1 effect of shading appears to be a persistent lowering of the 'carrying capacity' during this period.

With respect to individual species, significantly lower densities (52 to $84 \%$ ) due to shading were found in 3 of the 5 numerically dominant taxa (Fig. 6). Two of the dominant recolonizing taxa (the oligochaete Paranais litoralis, which arrived late in the experiment, and hydrobiid snails) showed no response to shading. $P$. litoralis is a generalist subsurface deposit feeder (Giere \& Pfannkuche 1982), and thus is less likely to respond to changes in the surficial microalgal film in the short term. Hydrobiids, in constrast, are known surface grazers on diatoms (Fenchel \& Kofoed 1976). Experiments by Levinton \& Bianchi (1981) suggest that the biomass of field hydrobiid populations is limited by benthic diatoms. Why they showed no response to shading in this experiment is difficult to explain. It is possible that this species responds to low food conditions with decreased growth but is relatively insensitive in regard to mortality (e.g. Levinton \& Bianchi 1981); or it may be that the gastropods are dying or emigrating but are being replaced with a constant or frequent supply of new recolonizers. It is possible that the shaded ponds can provide adequate food for the hydrobiids given the decrease in potential competitors, but it seems unlikely that the decrease in food from shading would exactly balance the competitive release to produce statistically identical populations sizes in the shaded and unshaded ponds.

In contrast to density, neither the community composition nor the taxonomic diversity showed a response to shading (Table 1). Shading was expected to cause a shift from surface-feeding species towards subsurface feeders or scavengers less immediately dependent on surface microalgae. This did not occur: the same suite of species was found regardless of shading. Time since recolonization began was the main factor in differentiating samples, and was largely driven by an increase in Paranais litoralis numbers late in the experiment (Fig. 4). Whether this is a successional pattern or a seasonal cycle in recruitment or mortality can not be determined from this experiment. $P$. litoralis reproduces primarily by asexual paratomy (Nilsson et al. 1997), and is characterized by low background numbers seasonally punctuated by large brief peaks (Giere \& Pfannkuche 1982, Cheng et al. 1993).

While there was a significant effect of sampling day on diversity, this followed no directed trend: diversity neither increased nor decreased with time since disturbance. Overall, there was little suggestion in either community composition or diversity of a strong 'successional' pattern. Nor, with the exception of Paranais litoralis, was there a trend of early dominance by opportunists, or replacement of the first colonizers by later species.

The goal of this study was to determine if reduced microalgae, not shading per se, limited or altered macrofaunal colonization. The microalgae demonstrated a strong response to shading. Standing stocks of chlorophyll in shaded ponds were significantly lower in comparison with unshaded ponds (Table 1, Fig. 3). The significant decrease in dissolved oxygen in the shaded ponds (Table 1, Fig. 2) also supports the hypothesis of a shading effect on microalgae; rough calculations indicate that GPP is an order of magnitude lower in shaded ponds than in control ponds. While the GPP calculations contain assumptions that make their absolute values questionable, it is hard to identify a factor other than production that is able to drive oxygen differences of this magnitude in ponds that are of equal size, depth, and intertidal level and exposed to the same wind and weather conditions.

Knowledge of the feeding modes of the dominant species in the mesocosms supports the hypothesis that the shading effects found were due to changes in microalgal food resources: Hobsonia florida is a surface deposit feeder whose density declines when diatom production is decreased (Hentschel \& Jumars 1994); Chironomus sp. larvae are either surface deposit feeders or suspension feeders (Berg 1995); and Laeonereis culveri is a deposit feeder known to graze almost exclusively on benthic diatoms (Mazurkiewicz 1975).

A second consequence of shading was reflected in the dissolved oxygen levels of the ponds. Shaded ponds had persistent low DO levels, while control ponds exhibited higher DO levels during the day (Table 1, Fig. 2). The oxygen minima were sometimes at levels known to cause stress to a variety of benthic macrofaunal species ( $<2$ to $3 \mathrm{mg} \mathrm{l}^{-1}$ : Diaz \& Rosenberg 1995). Therefore, impacts due to shading could have resulted from either the persistent oxygen stress in the shaded ponds or food limitation. However, analyses of samples taken after aeration began detected no significant effects of oxygenation on any of the biological factors measured: chlorophyll and macrofaunal densities, diversity or evenness (Table 1), nor was there any trend in the data indicating a divergence of community responses in the oxygenated and unoxygenated ponds within each level of the shading treatment. Therefore, while a continuing effect of the early DO difference cannot be excluded, it seems unlikely that DO was responsible for the macrofaunal response to shading.

It is also possible that other factors altered by shading affected the macrofauna. Temperatures in the 
shaded ponds were slightly lower than in the unshaded ponds, but one would expect macrofauna in shallow ponds during the summer to benefit from lower temperatures, not to respond with lower densities. The epibenthic predator community was not assessed during the experiment. Important predator effects have been seen in similar macrofaunal communities (Peterson 1979, Kneib 1984). However, for the observed shading effect on macrofaunal density to be explained by predation differences, numbers or feeding efficiency of predators would have to be influenced directly by either shading or microalgal biomass. We know of no research documenting such a response. In contrast, benthic macrofauna are known to both feed on microalgae and respond to increases in food resources with population increases (e.g., Grassle et al. 1985, Snelgrove et al. 1992, Hentschel \& Jumars 1994, Renaud et al. 1999). Parsimony therefore suggests that a predator response is less likely, but it remains an important hypothesis to be tested.

The conclusion, if accepted, that recolonization by the benthic macrofaunal community in these mesocosms is food-limited by microalgae raises several interesting questions for future investigation.

Firstly, what is the precise nature of the trophic effect of reduced microalgae? This study did not differentiate benthic from pelagic microalgae (phytoplankton are as likely to be affected by shading as the microphytobenthos). Although Chironomus sp. was the only taxon characterized as a suspension-feeder, does sedimenting phytoplankton comprise an important food component of the community? What is the importance of production versus biomass of the microalgae? Are the macrofauna responding to overall microalgal biomass, or to changes in the species composition, or to the food quality of the microalgae? These questions could be answered by a study examining the microalgal community in more detail in shaded and unshaded ponds.

Secondly, it would be interesting to resolve the lifehistory stage and process through which food limitation affects populations and communities (e.g., larval settlement/selectivity, early post-settlement mortality, post-settlement immigration, and/or later growth and survival). A study using similar experimental methods but taking samples more frequently with a smaller sieve mesh and measuring sizes of all individuals would be valuable for tracking settlement rates and size-specific growth and mortality. Not all colonizers were settling juveniles. The size spectrum of colonizers could not be determined because many of the settling juveniles were small enough to pass through the $300 \mu \mathrm{m}$ mesh used, but large juveniles and adults of the polychaete species were consistently found, even in the earliest samples.
Thirdly, what is the applicability of these results to natural habitats? The levels of chlorophyll in both the shaded and unshaded ponds were well within the range found in natural intertidal and shallow subtidal estuarine habitats (Heip et al. 1995, Herman et. al. 1999). Given that the 'disturbance' (sediment defaunation) and the treatments were applied at the scale of the whole mesocosm, and that the mesocosms used were in the same size range as small natural ponds (K. I. Stocks pers. obs.), no assumptions about scaling are required to interpret the results for ponds. Also, although there were no nearby natural marsh ponds suitable for comparison, there is little to indicate that the community in the mesocosms differed substantially from that which would be expected in natural marsh ponds, or that the distance to nearby natural marsh ponds consituted a recruitment limitation. Benthic macrofaunal sampling from ponds in Spartina marshes is scant (Heck et al. 1995 and Stocks 2000 for general macrofauna; Campbell \& Denno 1978 for insects) and indicates that communities supported by different ponds can vary substantially. However all the taxa found in the mesocosms were common constituents of saltmarsh ponds or other shallow soft-sediment habitats, and there are no taxa common to all of the previous pond studies that were absent from the mesocosms.

This study does not eliminate a potential role for other processes in structuring pond communities and, like all habitats, it is almost certain that the benthic community is affected by a complex interaction of factors that vary over space and time (i.e. as reproductive cycles change the supply of potential recruits through time, and food resources and predator populations fluctuate). However, this study lends support to the hypothesis that the primarily deposit feeding, benthic macrofaunal community studied relies on microalgae for food, and that it can be food limited at least during parts of the year.

Acknowledgements. Our thanks to Jean Marie Hartman for facilitating this project, and to Megan Cummings, Mike Stringer, and Pat McGrath for laboratory and field assistance. This article benefited from the constructive comments of Judith Grassle, Brian Hentschel, Lisa Levin, Sybil Seitzinger, Gary Taghon and 3 anonymous reviewers. Support was provided by National Science Foundation STAR fellowship U914949 and a contract from Ducks Unlimited.

\section{LITERATURE CITED}

Berg MB (1995) Larval food and feeding behaviour. In: Armitage PD, Cranston PS, Pinder LCV (eds) The Chironomidae: biology and ecology of non-biting midges. Chapman \& Hall, London, p 136-168

Campbell BC, Denno RF (1978) The structure of the aquatic insect community associated with intertidal pools in New Jersey. Ecol Entomol 3:181-187 
Chen CC, Peterson JE, Kemp WM (1997) Spatial and temporal scaling of periphyton growth on walls of estuarine mesocosms. Mar Ecol Prog Ser 155:1-15

Cheng IJ, Levinton JS, McCartney M, Martinez D, Weissburg MJ (1993) A bioassay approach to seasonal variation in the nutritional value of sediment. Mar Ecol Prog Ser 94: 275-285

Currin CA, Joye SB, Paerl HW (1995) The role of standing dead Spartina alterniflora and benthic microalgae in salt marsh food webs: considerations based on multiple stable isotope analysis. Mar Ecol Prog Ser 121:99-116

Dauer DM, Simon JL (1976) Habitat expansion among polychaetous annelids repopulating a defaunated marine habitat. Mar Biol 37:169-177

Diaz RJ, Rosenberg R (1995) Marine benthic hypoxia: a review of its ecological effects and the behavioural responses of benthic macrofauna. Oceanogr Mar Biol Annu Rev 33:245-303

Fenchel T, Kofoed LH (1976) Evidence for exploitative interspecific competition in mud snails (Hydrobiidae). Oikos 27:367-376

Forbes TL, Lopez GL (1990) The effect of food concentration, body size, and environmental oxygen tension on the growth of the deposit-feeding polychaete, Capitella species 1. Limnol Oceanogr 35:1535-1544

Giere O, Pfannkuche O (1982) Biology and ecology of marine Oligochaeta. A review. Oceanogr Mar Biol Annu Rev 20: 173-308

Grassle JF, Grassle JP, Brown-Leger LS, Petrecca RF, Copley NJ (1985) Subtidal macrobenthos of Narragansett Bay. Field and mesocosm studies of the effects of eutrophication and organic input on benthic populations. In: Gray JS, Christiansen ME (eds) Marine biology of polar regions and effects of stress on marine organisms. John Wiley \& Sons Ltd, New York, p 421-434

Grémare A, Marsh AG, Tenore KR (1989) Secondary production and reproduction of Capitella capitata type I (Annelida: Polychaeta) during a population cycle. Mar Ecol Prog Ser 51:99-5

Hall SJ, Raffaelli DG, Thrush SF (1992) Patchiness and disturbance in shallow water benthic assemblages. In: Giller PS, Hildrew AG, Raffaelli DG (eds) Aquatic ecology: scale, pattern and process. Blackwell Scientific Publications, Oxford, p 333-375

Heck KL, Able KW, Roman CT, Fahay MP (1995) Composition, abundance, biomass, and production of macrofauna in a New England estuary: comparisons among eelgrass meadows and other nursery habitats. Estuaries 18: 379-389

Heip CHR, Goosen NK, Herman PMJ, Kromkamp J, Middleburg JJ, Soetaert K (1995) Production and consumption of biological particles in temperate tidal estuaries. Oceanogr Mar Biol Annu Rev 33:1-149

Hentschel BT, Jumars PA (1994) In situ chemical inhibition of benthic diatom growth affects recruitment of competing, permanent and temporary meiofauna. Limnol Oceanogr 39:816-838

Herman PMJ, Middleburg JJ, van de Koppel J, Heip CHR (1999) Ecology of estuarine macrobenthos. Adv Ecol Res 29:195-240

Kneib RT (1984) Patterns of invertebrate distribution and abundance in the intertidal salt marsh: Causes and questions. Estuaries 7:392-412

Levin LA, Creed EL (1986) Effects of temperature and food availability on reproductive responses of Streblospio benedicti (Polychaeta: Spionidae) with planktotrophic or lecithotrophic development. Mar Biol 92:103-113
Levinton JS, Bianchi TS (1981) Nutrition and food limitation of deposit-feeders. I. The role of microbes in the growth of mud snails (Hydrobiidae). J Mar Res 39:531-545

Libes SM (1992) An introduction to marine biogeochemistry. John Wiley \& Sons Inc, New York

Lopez GR, Levinton JS (1987) Ecology of deposit-feeding animals in marine sediments. Q Rev Biol 62:235-260

MacIntyre HL, Geider RJ, Miller DC (1996) Microphytobenthos: the ecological role of the 'secret garden' of unvegetated, shallow-water marine habitats. I. Distribution, abundance and primary production. Estuaries 19: $186-201$

Marino R, Howarth RW (1993) Atmospheric oxygen exchange in the Hudson River: dome measurements and comparison with other natural waters. Estuaries 16:433-445

Marsh AG, Tenore KR (1990) The role of nutrition in regulating the population dynamics of opportunistic, surface deposit feeders in a mesohaline community. Limnol Oceanogr 35:710-724

Mazurkiewicz M (1975) Larval development and habits of Laeonereis culveri (Webster) (Polychaeta: Nereidae). Biol Bull 149:186-204

Middelburg JJ, Barranguet C, Boschker HTS, Herman PMJ, Moens T, Heip CHR (2000) The fate of intertidal microphytobenthos carbon: an in situ ${ }^{13} \mathrm{C}$-labeling study. Limnol Oceanogr 45:1224-1234

Miller DC, Geider RJ, MacIntyre HL (1996) Microphytobenthos: the ecological role of the 'secret garden' of unvegetated, shallow-water marine habitats. II. Role in sediment stability and shallow-water food webs. Estuaries 19: 202-212

Nilsson P, Kurdziel JP, Levinton JS (1997) Heterogenous population growth, parental effects and genotype-environment interactions of a marine oligochaete. Mar Ecol Prog Ser 130:181-191

Odum HT, Hoskin CM (1958) Comparative studies in the metabolism of marine waters. Contrib Mar Sci 5:16-46

Olafsson EB, Peterson CH, Ambrose WG (1994) Does recruitment limitation structure populations and communities of macro-invertebrates in marine soft sediments: the relative significance of pre- and post-settlement processes. Oceanogr Mar Biol Annu Rev 32:65-109

Parsons TR, Maita Y, Lalli CM (1984) A manual of chemical and biological methods for seawater analysis. Pergamon Press, New York

Peterson BJ, Howarth RW (1987) Sulfur, carbon, and nitrogen isotopes used to trace organic matter flow in the saltmarsh estuaries of Sapelo Island, Georgia. Limnol Oceanogr 32:1195-1213

Peterson BJ, Howarth RW, Garritt RH (1986) Sulfur and carbon isotopes as tracers of salt-marsh organic matter flow. Ecology 67:865-874

Peterson CH (1979) Predation, competitive exclusion, and diversity in the soft-sediment benthic communities of estuaries and lagoons. In: Livingston RJ (ed) Ecological processes in coastal marine systems. Plenum Press, New York, p 233-264

Peterson JE, Chen CC, Kemp WM (1997) Scaling aquatic primary production: experiments under nutrient- and lightlimited conditions. Ecology 78:2326-2338

Pielou EC (1969) An introduction to mathematical ecology. Wiley, New York

Posey MH, Alphin TD, Cahoon L, Lindquist D, Becker ME (2000) Interactive effects of nutrient additions and predation on infaunal communities. Estuaries 22:785-792

Renaud PE, Syster DA, Ambrose WG (1999) Recruitment patterns of continental shelf benthos off North Carolina, USA: 
effects of sediment enrichment and impact on community structure. J Exp Mar Biol Ecol 237:89-106

Rhoads DC, McCall PL, Yingst JY (1978) Disturbance and production on the estuarine seafloor. Am Sci 66:577-586

Smith CR, Brumsickle SJ (1989) The effects of patch size and substrate isolation on colonization modes in intertidal sediments. Limnol Oceanogr 34:1263-1277

Snelgrove PVR, Grassle JF, Petrecca RF (1992) The role of food patches in maintaining high deep-sea diversity: field experiments with hydrodynamically unbiased colonization trays. Limnol Oceanogr 37:1543-1550

Stiven AE, Kuenzler EJ (1979) The response of two salt marsh molluscs, Littorina irrorata and Geukensia demissa, to field manipulations of density and Spartina litter. Ecol Monogr 151-171

Stocks KI (2000) Factors affecting macroinfaunal community structure in salt marshes. PhD thesis, Rutgers, The State University of New Jersey, New Brunswick

Sullivan MJ, Moncreiff CA (1990) Edaphic algae are an important component of salt marsh food-webs: evidence from multiple stable isotope analyses. Mar Ecol Prog Ser 62:149-159

Tenore KR, Chesney EJ (1985) The effects of interaction of rate of food supply and population density on the bioenergetics of the opportunistic polychaete, Capitella capitata (Type 1). Limnol Oceanogr 30:1188-1195

Editorial responsibility: Ronald Kneib (Contributing Editor), Sapelo Island, Georgia, USA
Trueblood DD, Gallagher ED, Gould DM (1994) Three stages of seasonal succession on the Savin Hill Cove mudflat, Boston Harbor. Limnol Oceanogr 39:1440-1454

Underwood GJC, Kromkamp J (1999) Primary production by phytoplankton and microphytobenthos in estuaries. Adv Ecol Res 29:93-153

Weinberg JR (1979) Ecological determinants of spionid distributions within dense patches of the deposit-feeding polychaete Axiothella rubrocincta. Mar Ecol Prog Ser 1: 301-314

Whitlatch RB (1980) Patterns of resource utilization and coexistence in marine intertidal deposit-feeding communities. J Mar Res 38:743-765

Whitlatch RB (1981) Animal-sediment relationships in intertidal marine benthic habitats: some determinants of deposit-feeding species diversity. J Exp Mar Biol Ecol 53: 31-45

Zajac RN (1986) The effects of intra-specific density and food supply on growth and reproduction in an infaunal polychaete, Polydora ligni Webster. J Mar Res 44: 339-359

Zajac RN, Whitlatch RB (1982) Responses of estuarine infauna to disturbance. I. Spatial and temporal variation of initial recolonization. Mar Ecol Prog Ser 10:1-14

Zar JH (1999) Biostatistical analysis, 4th edn. Prentice-Hall, Inc, Upper Saddle River, NJ

Submitted: July 23, 2000; Accepted: April 4, 2001 Proofs received from author(s): October 2, 2001 
